\title{
Population structure of Poecilia mexicana (native) and Poeciliopsis gracilis (non-native) in a subtropical river
}

\author{
María Pamela Bermúdez-González ${ }^{1}$, Arely Ramírez-García ${ }^{2}$, Estefanía del Carmen Velázquez-García ${ }^{3}$ \\ Mónica Elisa Queijeiro-Bolaños ${ }^{3}$ \& Juan Pablo Ramírez-Herrejón ${ }^{4}$ \\ ${ }^{1}$ Programa Institucional de Doctorado, Facultad de Ciencias Naturales Campus UAQ-Juriquilla \\ Universidad Autónoma de Querétaro (UAQ), Jáuregui, Querétaro, México \\ ${ }^{2}$ Programa Institucional de Doctorado en Ciencias Biológicas, Universidad Michoacana de \\ San Nicolás de Hidalgo, Morelia, Michoacán, México \\ ${ }^{3}$ Facultad de Ciencias Naturales Campus UAQ-Juriquilla, Universidad Autónoma de Querétaro (UAQ) \\ Querétaro, México \\ ${ }^{4}$ CONACYT-Universidad Autónoma de Querétaro, Campus UAQ-Aeropuerto \\ Querétaro, México \\ Corresponding author: Juan Pablo Ramírez-Herrejón (ramirezherrejon@ gmail.com)
}

\begin{abstract}
Despite the increase of exotic species in bodies of water, studies on the population structure of coexisting native and exotic fish species are rare. We evaluated the population structure of the native Poecilia mexicana and non-native Poeciliopsis gracilis species in an environmental gradient and its relation to the habitat characteristics in the Jalpan River, located in the state of Queretaro, Mexico. We calculated size structure, sex ratio, gonad stage, and condition factor for both species. Visual-based habitat quality, riparian quality, and physical and chemical characteristics of water were also evaluated. A total of 322 individuals of $P$. gracilis and 762 of $P$. mexicana were captured with different fishing nets due to the habitat heterogeneity. Study sites were classified into three categories of habitat conditions: poor, marginal, and sub-optimal. P. mexicana females showed a complete structure of sizes in the poor habitat category. $P$. gracilis did not show a complete structure in any habitat category. The sub-optimal category of habitat conditions had the lowest number of specimens for both species. Poor category showed a sex ratio of 1:1 (females: males) for $P$. mexicana while in $P$. gracilis, females were more abundant than males (sex ratio 5:1). Fulton's factor was higher for $P$. mexicana than for $P$. gracilis. Our results showed that habitat quality of the river affected size structure, stages of development, and sex ratio of the two species, but did not show conclusive evidence of favored species or reproductive competition.
\end{abstract}

Keywords: Poeciliidae; population ecology; habitat condition; non-native fish; sub-tropical river; environmental gradient

\section{INTRODUCTION}

The establishment of exotic species populations is considered the second most important cause of biodiversity loss (Wilcove et al., 1998; Dudgeon et al., 2006) due to the impacts that these populations cause on the ecosystems into which they are introduced (Dudgeon et al., 2006). In Mexico, the introduction of exotic fish species is considered a widespread problem (Contreras-Balderas et al., 2008), since it threatens freshwater ecosystems. This problem has become criti- cal in areas such as the central region of Mexico, which harbors a high richness of endemic fish fauna (Miller, 2009). Aquatic systems in this region have been impacted by human activities, which adversely affects native fish, as it is the possible cause of extinction of several freshwater fish species (e.g., Chirostoma bartoni and C. charari) (Domínguez-Domínguez et al., 2006; Mercado-Silva et al., 2009). Also, the introduction of species can alter the chemical and physical composition of freshwater ecosystems (ContrerasMacBeath, 2005), and there is little understanding of 
their effect on these systems, particularly on the population decline of the native species (Mitchell \& Knouft, 2009).

The population structure of non-native fish species with invasive potential has been poorly documented. Such is the case of the Poeciliidae family species in Mexico, where they have been widely introduced into freshwater ecosystems, mainly by aquarists or as stowaways in the process of introducing fish species of commercial importance (Mejía-Mojica, 1992). An example of a poeciliid invasive species is Poeciliopsis gracilis, which is native of the Atlantic slope in the state of Veracruz and Oaxaca (Miller, 2009). This species can survive in lentic and lotic systems, tolerates poor water quality, and has a high reproductive rate (MejíaMojica, 1992). However, studies about this species are scarce and highly localized (Gómez-Marquez et al., 2008). This species has been introduced in the Balsas River (states of Michoacán, Guerrero, and Morelos) and the rivers of the Sierra Gorda Biosphere Reserve (SGBR) located in the state of Queretaro (Miller, 2009). In particular, the SGBR is considered one of the most important preserved zones of Mexico, with many endemic fish species, and the impact of the introduction of the non-native $P$. gracilis on native fish is of concern (Soto-Galera et al., 2019).

One of the native fish species in the SGBR is Poecilia mexicana which occurs together with $P$. gracilis in the Jalpan River. This river has an environmental gradient of physical conditions of the habitat, caused by anthropic activities (Torres-Olvera, 2018).

In freshwater systems, the anthropic activities impart detrimental effects on native fish but are advantageous for non-native fish (Ramírez-Herrejón et al., 2014; Ramírez-García et al., 2017). The negative effect on aquatic ecosystems caused by anthropic activities open new "vacancies" understood as opportunities to reproduce, feed and take refuge for species with higher tolerance capacities to environmental stressors and more adaptable to the new environment (Ruiz et al., 1999). Moreover, as a result of degradation, the quantity and quality of critical habitats for native organisms are altered, and native species are more vulnerable to competition and depredation by non-native species, which can be more tolerant of this condition (Meador et al., 2003). Even more, the degree of biological invasion can be an indicator of freshwater systems degradation on a larger scale, for example, if the invasive species are detected in the upper, middle and lower zones of one basin (Karr et al., 1985; Hughes \& Gammon, 1987).

On the other hand, the construction of dams has hindered the connectivity of river flows and has increased the abundance of lentic habitats, facilitating the existence of non-native species (Havel et al., 2005, 2015). This advantage maybe even more important when the origin of the non-native species is related to lentic systems, such as fishes of the Poeciliidae family. In this sense, the physical anthropic degradation of the Jalpan River is mainly caused by the two dams, the Presa Jalpan and the Presa Vieja, that were constructed more than 30 years ago. The Presa Jalpan works as a functional dam and represents a point of retention of the flow in the Jalpan River, and the Presa Vieja is a nonfunctional dam, which structure represents a point of diversion of the flow (Torres-Olvera, 2018). The limitation of the river flow during most of the year has caused that it became in a continuum of interconnected deep and shallow pools (Torres-Olvera, 2018). This phenomenon seems to turn the lotic ecosystem into various interconnected lentic systems; in this context, the interrupted connectivity of water flow and the higher level of disturbance act as stepping-stones for the dispersal of the exotic species making it susceptible to invasion (Havel et al., 2005).

For these reasons, the Jalpan River offers a unique opportunity to research the ecological interaction between two fish species of the same family, with similar ecological function but different origin; specifically, the relationship between the population structure of both species and the habitat characteristics, which have not been yet documented. We hypothesized that the non-native fish species could be favored by environmental degradation, unlike the native fish, which usually are negatively impacted by anthropic activities on aquatic ecosystems. We expected a more notable size structure and higher condition factor and reproduction rate of $P$. gracilis. The study aim was to describe the population structure of $P$. gracilis and $P$. mexicana in an environmental quality gradient in a subtropical river.

\section{MATERIALS AND METHODS}

\section{Study area}

The Jalpan River is located in the north of the state of Querétaro, Mexico, between $21^{\circ} 6^{\prime} \mathrm{N}, 99^{\circ} 36^{\prime} \mathrm{W}$ and $21^{\circ} 22^{\prime} \mathrm{N}, 99^{\circ} 20^{\prime} \mathrm{W}$. Nine study sites along the river were selected (based on visual-based habitat assessment (VBHA)), from its origin to the union with the Santa María River (Fig. 1). The sites selected were: Purísima de Arista (PA), Trapiche (TR), Presa Vieja (PV), La Playita (PL), Puente USEBEQ (PU), Saldiveña (SG), Río Adentro (RA), Desembocadura (DS) and Santa María (SM). On each site, we defined one river section as the equivalent to five times the river width, based on the maximum riverside distance, following the official criteria of the ecological flow in 


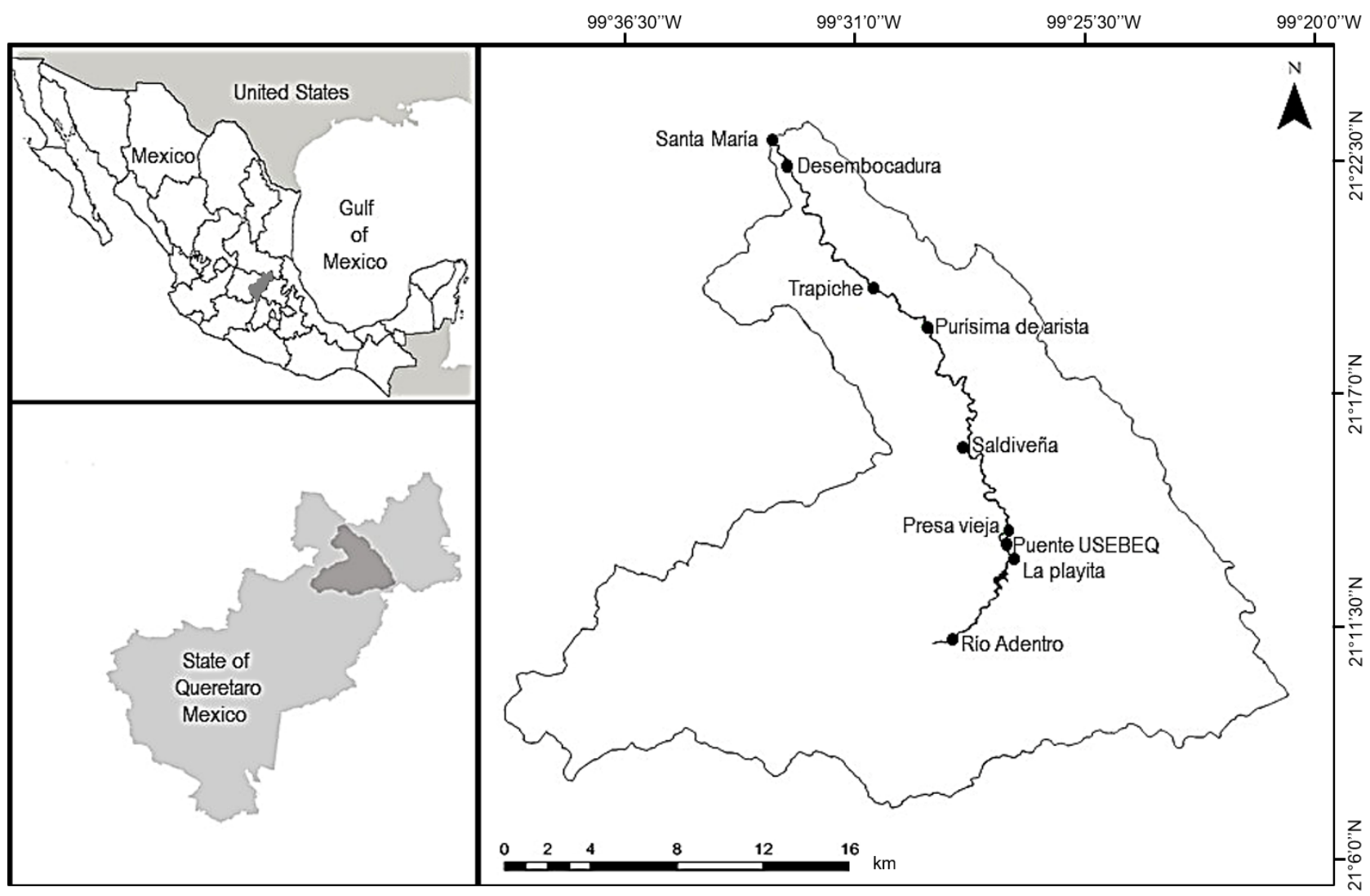

Figure 1. Location of the study sites along the Jalpan River, Mexico.

Mexico (NMX-AA-159-SCFI-2012; DOF, 2012). The river sections were selected to make the sampling area among sites comparable.

The study was carried out during the dry season at three different times. The first fieldwork was done during April-May 2016; the second was made in the driest season before the rains in July 2016, and the third one was made in the early dry season of DecemberJanuary 2017. The rainy season (August-November 2016) was not included in the research because the Jalpan River represents a type A river, following the stream classification of Rosgen (1985), where the increase of the river flow makes impossible safe sampling. The fieldwork was done during the dry season because i) the dry season represents a more stable habitat condition (Lyons et al., 1995; PérezMunguía et al., 2007), ii) human impacts are enhanced, creating spatial variation along the length of the river system, and, iii) to compare with previous studies because research on river ecology is commonly done during the dry season (Moncayo-Estrada et al., 2015).

The environmental quality gradient in the study sites was evaluated through the physical condition of the river, the riparian vegetation condition, and the physical and chemical characteristics of the water. The physical condition of the river was estimated with the attributes described in the visual-based habitat assessment (VBHA) proposed by Barbour et al. (1999). It includes variables as sinuosity, materials of the substrate and the banks, sediment retention points, condition of riparian vegetation and riparian zone, and the status of the floodplain. These variables showed the structure of the adjacent physical habitat that affects the condition of the resident aquatic community (Barbour et al., 1999), and this physical structure does not change with the rainy season; for this reason, we evaluated it only once to represent the dry season. This method classifies the habitat quality in four categories, optimal, sub-optimal, marginal, and poor.

The VBHA have two approaches, one designed for high-gradient streams and one designed for lowgradient streams. The natural high-gradient streams have substrates composed mainly by coarse sediment particles, such as gravel, and the combination of riffle/run is predominant. The natural low-gradient streams have substrates composed mainly by fine sediment particles, such as sand, and the combination of glide/pool is predominant (Barbour et al., 1999). Based on these approaches, eight sampling sites were 
Table 1. Habitat quality gradient of each study site in the Jalpan River based on the visual-based habitat assessment (VBHA) and the Riparian Quality Index (RQI).

\begin{tabular}{|c|c|c|c|c|c|}
\hline Sites & Gradient & VBHA value & Category & RQI value & Category \\
\hline Purísima de Arista & High & 71 & Poor & 75 & Moderate \\
\hline Trapiche & High & 114 & Marginal & 110 & Good \\
\hline Presa Vieja & High & 79 & Poor & 96 & Moderate \\
\hline La Playita & High & 101 & Poor & 69 & Poor \\
\hline Pte. USEBEQ & High & 120 & Marginal & 41 & Poor \\
\hline Saldiveña & High & 93 & Poor & 52 & Poor \\
\hline Río Adentro & High & 137 & Marginal & 130 & Very Good \\
\hline Desembocadura & High & 122 & Marginal & 147 & Very Good \\
\hline Santa María & Low & 155 & Sub-optimal & 148 & Very Good \\
\hline
\end{tabular}

located in high gradient, and only Santa María was considered as a low gradient (Table 1).

The riparian vegetation condition was assessed with the riparian quality index of González del Tánago \& García de Jalón (2011), which includes variables as the width of riparian corridor, longitudinal continuity, lateral and vertical connectivity, the structure of vegetation and age diversity. The physical and chemical characteristics of the water, including water temperature $\left(\mathrm{C}^{\circ}\right)$, $\mathrm{pH}$, dissolved oxygen $\left(\mathrm{mg} \mathrm{L}^{-1}\right)$, total dissolved solids $\left(\mathrm{mg} \mathrm{L}^{-1}\right)$, oxidation-reduction potential $(\mathrm{mv})$, transparency $(\mathrm{cm})$, and turbidity (NTU), were measured for triplicate with a multisensor Hydroment Quanta (Loveland Colorado, USA). The combination of this information provides the possible presence of physical and chemical stressors that could affect the aquatic community (Barbour et al., 1999).

Sampling was carried out during the day, between 10:00 and 15:00 $\mathrm{h}$, including all potential habitat of poeciliid fish along the river section selected for each study site. Fish were captured with several fishing techniques: cast net $(4.0 \mathrm{~m}$ wide, $0.53 \mathrm{~mm}$ mesh size), electrofishing $(120 \mathrm{~V}, 60 \mathrm{~Hz}, 0.6-0.8 \mathrm{~A})$, seine net $(2.0$ $\mathrm{m}$ wide, $1.5 \mathrm{~m}$ high and $0.005 \mathrm{~m}$ mesh size), and hand nets (400 mm wide, $50 \mathrm{~mm}$ mesh size), to ensure the capture of different sizes of poeciliid fish in all hydromorphologic conditions. The capture effort was $30 \mathrm{~min}$ for each fishing technique, which was used along each river section. Fish were preserved in $70 \%$ ethanol and transported in plastic containers to the Laboratory of Biotic Integrity of the Autonomous University of Queretaro, Queretaro City, where they were identified (Miller, 2009), counted, measured $(0.01 \mathrm{~mm})$, and weighed following the criteria of Contreras-MacBeath \& Ramírez-Espinoza (1996).
Population size-structure was analyzed along the VBHA because it evaluates the habitat structure that influences water quality and the physical condition in which the aquatic community resides (e.g., variety and substrate quality, channel morphology and riparian vegetation), it also characterizes the micro-scale habitat (e.g., estimation of embeddedness) and macro-scale (e.g., channel morphology). We grouped all the data into standard length (SL) ranges following Sturges (1926). We calculated overall population abundance (juveniles, males, and females together) per sampling occasion as the ratio between the total number of captured fish (total $n$ ) and the estimated occasionalspecific values of $P<0.05$ for all the individuals pooled into a single group. Sex ratios were calculated as the ratio between the estimated number of adult females and males present in each population; the statistical significance of the sampling sites ratio results was set by a fit to the Chi-squared test $\left(\chi^{2}\right)$, using a $P<0.05$ value (Sparre \& Venema, 1997). The frequency of the gonadic maturity stages was estimated, according to Contreras-MacBeath \& Ramírez-Espinoza (1996) (Table 2). The fish condition was assessed with Fulton's condition factor $(\mathrm{K})$, used to compare the "condition" or "fatness" of fish, based on the assumption that heavier fishes of a given length are in better condition (Froese, 2006). SL at first maturity (L50) was related to SL using the logistic regression model to fit sigmoid curves according to the equation: $\mathrm{M}(\mathrm{L})=1 /\left(1+\mathrm{e}^{(-\mathrm{a}+\mathrm{b})}\right)$. Confidence limits were derived by Bayesian inference based on stochastic simulation. The allometric growth model was evaluated by linear regression, calculating the values of $a$ and $b$ of the equation $W=a L^{b}$, where: $\mathrm{W}$ is the body weight, $L$ is the standard length, $b$ is the growth exponent, or length-weight factor, and $a$ is a constant. The values of $a$ and $b$ were estimated using a linearized form (Froese, 2006), Tukey-test to evaluate significant differences in SL and weight between sexes. 
Table 2. Gonad maturity phases of viviparous fish (Contreras-MacBeath \& Ramírez-Espinoza, 1996).

\begin{tabular}{|c|c|}
\hline Phase & Description \\
\hline Stage I (immature) & $\begin{array}{l}\text { The ovaries were fusiform in shape and slightly thinner in their distal } \\
\text { portions. The color of the ovaries ranged from white to white-yellowish. }\end{array}$ \\
\hline Stage II (first reproduction) & The ovaries were flaccid, and their colored ranged from white to yellow. \\
\hline Stage III (ripening) & $\begin{array}{l}\text { The ovaries were amber in color due to the ovules, which measured from } \\
0.6 \text { to } 3 \mathrm{~mm} \text { in diameter. }\end{array}$ \\
\hline $\begin{array}{l}\text { Stage IV (ovules and } \\
\text { embryos) }\end{array}$ & $\begin{array}{l}\text { The ovaries had a mean width of } 5.2 \mathrm{~mm} \text { and a weight of } 0.37 \mathrm{~g} \text {. Embryos } \\
\text { of different developmental stages were present and were rolled over } \\
\text { themselves and positioned randomly in the gonad. Small white ovules were } \\
\text { also found in some ovaries. Frequently up to three broods at different } \\
\text { stages of development were observed in a single female, thus indicating } \\
\text { the existence of superfetation. }\end{array}$ \\
\hline Stage V (pre-parturition) & $\begin{array}{l}\text { These ovaries had a mean width of } 5.4 \mathrm{~mm} \text { and a weight of } 0.54 \mathrm{~g} \text {. They } \\
\text { were amber or brown-yellowish in color and had large, well-developed } \\
\text { embryos. }\end{array}$ \\
\hline Stage VI (spent) & The ovaries were elongated, flaccid and white, without embryos or ovules. \\
\hline
\end{tabular}

\section{RESULTS}

\section{Habitat condition}

We found a habitat quality gradient along the Jalpan river, where the values of the VBHA classified the study sites into three of four categories: poor, marginal, and sub-optimal; the optimal category was not found. The poor category included four study sites: Purísima de Arista, Presa Vieja, La Playita, and Saldiveña. These sites had substrate favorable for epifaunae, such as gravel, cobble, and boulder, but more than $75 \%$ of the habitat was surrounded by heavy deposits of fine sediment and mostly presented standing pools. The occurrence of riffles was infrequent. The riparian vegetation structure was not well-represented due to human activities, such as agriculture, cattle raising, and urbanization. The marginal category included four study sites: Trapiche, Puente USEBEQ, Río Adentro, and Desembocadura. This category showed substrate favorable for epifaunal colonization and fish cover, but the sediment deposition increased in bar formation, mostly from gravel, sand, and fine sediment. The channelization process was present; however, the occurrence of riffles was relatively frequent. The streambanks surface was generally protected by wellstructured riparian vegetation, and the riparian zone showed minimal human impacts. The sub-optimal category was represented by the study site, Santa María. This category presented a mixture of substrate favorable for epifaunae such as roots, submerged vegetation, woody debris, submerged logs, a mix of snags, and undercut banks. The channelization, dredging, and the sediment deposition were absent or minimal, and the vegetation of the riparian zone was preserved (Table 1).
The values of the Riparian Quality Index (RQI) showed four categories: poor, moderate, good, and very good. The category of poor included three sites: La Playita, Puente USEBEQ, and Saldiveña, where the width of the riparian corridor was fragmented by human action, with few vegetation forms, mainly adult individuals, soil surface sealed and riparian substratum substituted by inert materials. The category of moderate included two sites: Purísima de Arista and Presa Vieja, where the riparian corridor appeared in patches with the scarcity of understory strata, scarce representation of youngest age classes, and embankments infrequent. In general, the topography and substrate particle size had moderate alterations. The category of good was found in one site: Trapiche and the category of very good were found in three sites: Río Adentro, Desembocadura, and Santa María. These four sites showed continuity and coverage of riparian corridor in a natural condition, well-structured riparian vegetation with all age classes, channel and floodplain topography in a natural condition, and soil surface covered by vegetation detritus.

\section{Physical and chemical parameters}

The Santa Maria River showed the highest values of water temperature $\left(26.47 \pm 2.20^{\circ} \mathrm{C}\right)$, specific conductivity $\left(0.70 \pm 0.07 \mathrm{mS} \mathrm{cm}^{-1}\right)$, dissolved oxygen $(7.17 \pm$ $\left.0.93 \mathrm{mg} \mathrm{L}^{-1}\right)$, oxygen saturation $(111.24 \pm 7.54 \%)$, oxidation-reduction potential $(212.88 \pm 63.29 \mathrm{mv})$, and turbidity $(28.04 \pm 30.40$ NTU). The study site Río Adentro showed the lowest water temperature (20.18 \pm $\left.3.18^{\circ} \mathrm{C}\right)$. The lowest value of specific conductivity was found in the Puente USEBEQ $\left(0.35 \pm 0.06 \mathrm{mS} \mathrm{cm}^{-1}\right)$, and the lowest value of dissolved oxygen $(4.91 \pm 1.04$ $\mathrm{mg} \mathrm{L}^{-1}$ ) in Saldiveña. Trapiche showed the lowest value 


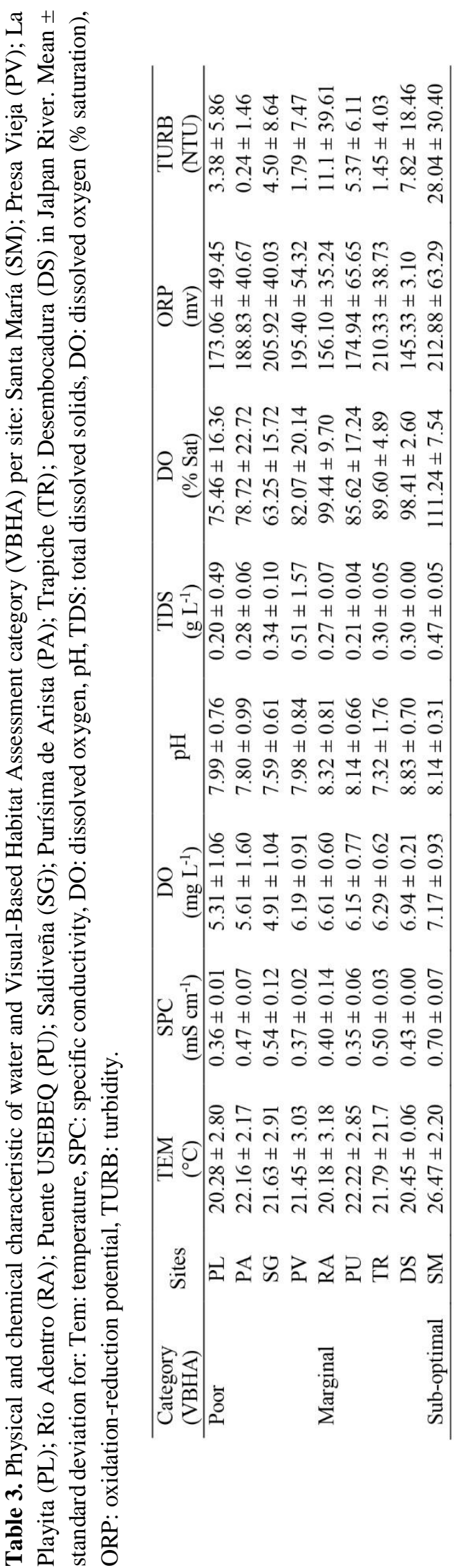

of $\mathrm{pH}(7.32 \pm 1.76)$, and Desembocadura showed the highest value $(8.83 \pm 0.70)$. Presa Vieja showed the highest total dissolved solids $\left(0.51 \pm 1.57 \mathrm{~g} \mathrm{~L}^{-1}\right)$, while the minimum value was found in La Playita $(0.21 \pm$ $\left.0.04 \mathrm{~g} \mathrm{~L}^{-1}\right)$. Saldiveña showed lower oxygen saturation $(63.25 \pm 15.72 \%)$. The lowest value of the reduction in oxygen potential was found in Desembocadura (145.33 $\pm 3.10 \mathrm{mv})$. The lower value of water turbidity $(0.24 \pm$ 1.46 NTU) was found in Purisima de Arista (Table 3).

\section{Population structure and reproduction}

A total of 322 individuals of Poeciliopsis gracilis and 762 individuals of Poecilia mexicana were captured along the Jalpan River (Table 4). P. mexicana showed a complete structure of sizes in the poor habitat category for females. The sub-optimal category of habitat condition presented the lower frequency of specimens for both species (both females ad males). The longest female of $P$. gracilis was $71 \mathrm{~mm}$ in SL in the marginal category and the smallest $14 \mathrm{~mm}$ in SL in the poor category. For males, the longest specimen was found in the sub-optimal category with $34 \mathrm{~mm}$ of SL, and the smallest was $16 \mathrm{~mm}$ in SL, in the poor category. For $P$. mexicana, the longest female and male were present in the poor category $(91 \mathrm{~mm}$ and $61 \mathrm{~mm}$ of SL, respectively), whereas the smallest female and male was $13 \mathrm{~mm}$ and $20 \mathrm{~mm}$ in SL, respectively; both found in the poor category (Fig. 2).

Poor category showed a sex ratio of 1:1 (females: males) for P. mexicana, whereas in marginal and suboptimal categories the females were predominant $\left(\chi^{2}=\right.$ 8.44, $P=0.001$ ); while in $P$. gracilis females were significantly predominant in all categories $\left(\chi^{2}=8.44, P\right.$ $=0.001$; Table 4).

Poor category showed a completed gonad stage for both species, except for males of $P$. gracilis, where a lower frequency of individuals was present in the three categories. In the poor category for $P$. mexicana, mature individuals (stages IV and V) were more frequent for both sexes (Fig. 3). We did not find any organism in stage VI (spent).

The marginal habitat category and the first dry season (April to May) showed the highest values of the Fulton factor $(\mathrm{K})$ for both species, and the poor category showed the lowest values of $\mathrm{K}$ for both species. Males presented lower values than females. In general, Fulton's factor was higher for P. mexicana than for $P$. gracilis (Fig. 4). The first maturity size for females of $P$. gracilis was established at $34.75 \mathrm{~mm}$ of SL, and for males at $24.70 \mathrm{~mm}$ of SL. Females of $P$. mexicana was established at $40.20 \mathrm{~mm}$ of SL and males at $33.33 \mathrm{~mm}$ of SL. 
Table 4. The number of captured individuals and sex ratio (female:male) of Poecilia mexicana $\left(\chi^{2}=8.44, P=0.001\right)$ and Poeciliopsis gracilis $\left(\chi^{2}=5.06, P=0.020\right)$ in the three categories of habitat quality during April-May- 2016, July 2016 and December 2016-January 2017 in the Jalpan River. ID: Insufficient data. $* P<0.05$.

\begin{tabular}{lccc}
\hline Species & Poor & Marginal & Sub-optimal \\
\hline P. mexicana & $348: 261$ & $111: 22$ & $14: 6$ \\
April-May 2016 & $3: 1$ & $3: 1$ & ID \\
July 2016 & $2: 1$ & $4: 1$ & $3: 1$ \\
December 2016-January 2017 & $2: 1$ & $14: 1$ & $1: 1$ \\
Total & $1: 1$ & $5: 1 *$ & $2: 1$ \\
\hline P. gracilis & $187: 43$ & $34: 16$ & $35: 7$ \\
April-May 2016 & $3: 1$ & $2: 1$ & ID \\
July 2016 & $5: 1$ & $1: 1$ & $4: 1$ \\
December 2016-January 2017 & $3: 1$ & $14: 1$ & ID \\
Total & $4: 1$ & $2: 1$ & $5: 1$ \\
\hline
\end{tabular}
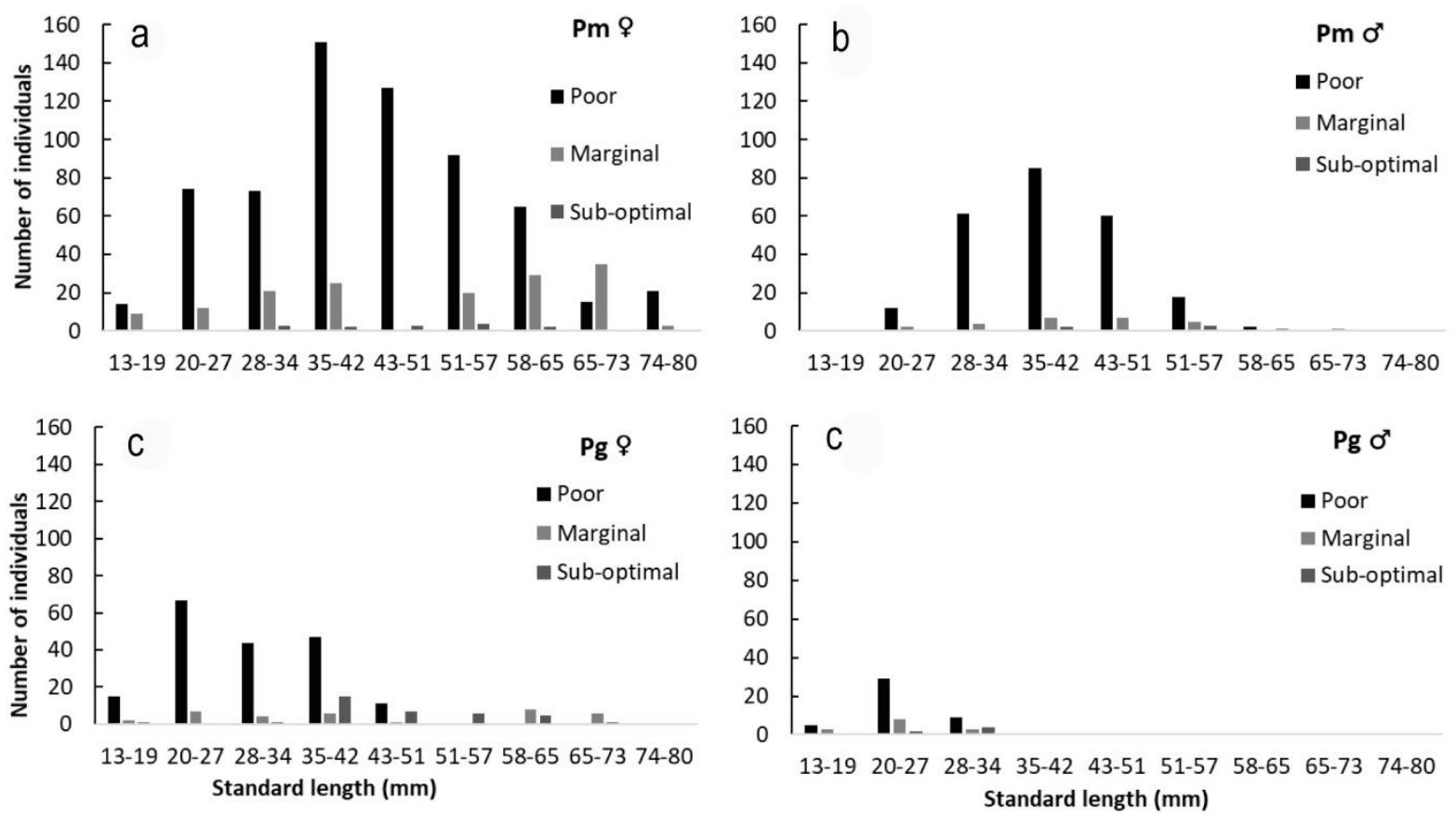

Figure 2. Structure of sizes in the three categories of visual-based habitat assessment (poor, marginal, sub-optimal) for females $(+$ ) and males $(\hat{)})$ of Poecilia mexicana $(\mathrm{Pm})$ and Poeciliopsis gracilis $(\mathrm{Pg})$ in the Jalpan River. a) Poecilia mexicana female data, b) Poecilia mexicana male data, c) Poeciliopsis gracilis female data, d) Poeciliopsis gracilis female data.

For $P$. gracilis, significant differences were observed $(P<0.0001)$ between sizes and weight by habitat category; females showed the smallest mean sizes and the lowest mean weight $(F=52.17 ; P=0.001)$ in the poor category $(\mathrm{SL}=30.1 \pm 8.0 \mathrm{~cm}$ and weight= $0.5 \pm 0.4 \mathrm{~g})$ and the largest mean sizes in the suboptimal category $(\mathrm{SL}=47.6 \pm 10.1 \mathrm{~cm}$ ), highest mean weight in the marginal category $(2.9 \pm 2.84 \mathrm{~g})$. For males, the smallest mean sizes $(F=4.46, P=0.0150)$ were present in the marginal category $(\mathrm{SL}=23.8 \pm 3.8$ $\mathrm{cm})$ and the highest in the sub-optimal category ( $\mathrm{SL}=$ $30.3 \pm 3.3 \mathrm{~cm}$ ), the highest mean weight was in the sub- optimal category and the lowest in poor and marginal categories $(0.2 \pm 0.1 \mathrm{~g})$. Males showed negative allometric growth in the three categories. Females showed negative allometric growth in the poor category and positive allometric growth in the marginal and suboptimal categories (Table 5). Females of P. mexicana did not present significant differences between the mean size in the three categories $(P>0.1)$. The males showed significant differences and the biggest size (SL $=50.1 \pm 8.0 \mathrm{~cm} ; P<0.0001)$ in the sub-optimal category. The weight of females and males presented significant differences. Poor category presented the lowest 

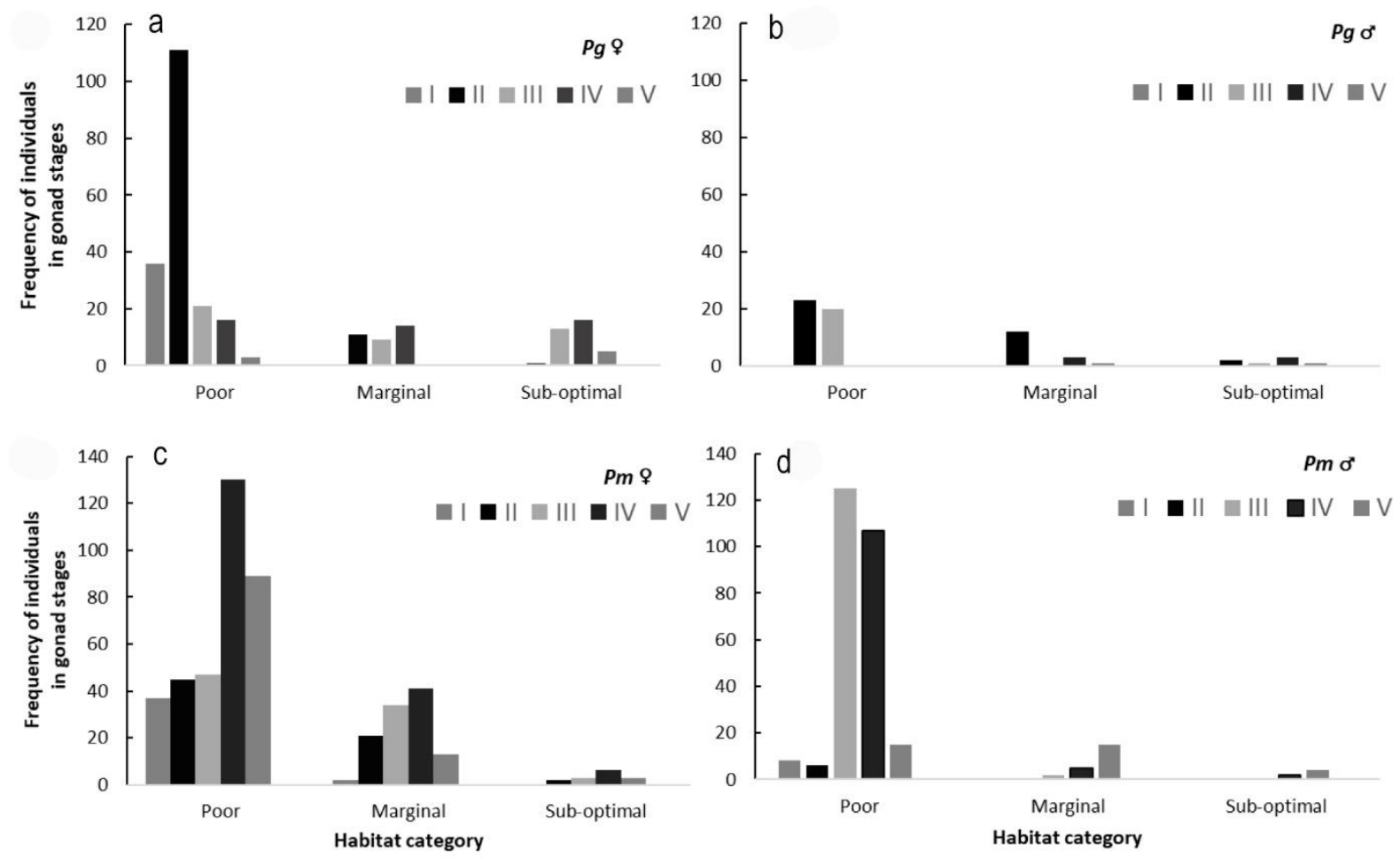

Figure 3. Frequency of individuals of each gonad stage in the three categories of habitat quality for females ( $P$ ) and males $\left({ }^{3}\right)$ of Poeciliopsis gracilis $(\mathrm{Pg})$ and Poecilia mexicana $(\mathrm{Pm})$ in the Jalpan River. a) Poeciliopsis gracilis female data, b) Poeciliopsis gracilis male data, c) Poecilia mexicana female data, d) Poecilia mexicana male data.

Table 5. Mean standard length (SL) \pm standard deviation (SD), mean weight $\pm \mathrm{SD}$, and the determination coefficient $\left(R^{2}\right)$ between SL $(\mathrm{cm})$ and weight $(\mathrm{g})$ for Poecilia mexicana and Poeciliopsis gracilis by females and males in the three categories of habitat quality: poor, marginal and sub-optimal. ${ }^{+}$Positive allometry $(b>3)$, negative allometry $(b<3)$. Tukey test (superscript $\mathrm{a}$ and $\mathrm{b}$ ) showed significant differences in SL between habitat category.

\begin{tabular}{|c|c|c|c|c|c|c|c|c|c|c|}
\hline \multirow{2}{*}{ Species } & \multicolumn{2}{|c|}{ Mean SL \pm SD } & \multicolumn{2}{|c|}{ Mean weight \pm SD } & \multicolumn{2}{|c|}{$a$} & \multicolumn{2}{|c|}{$b$} & \multirow{2}{*}{$\frac{R^{2}}{q}$} & \multirow{2}{*}{$\frac{P<0.01}{\delta^{\lambda}}$} \\
\hline & q & $0^{1}$ & q & $0^{\lambda}$ & q & $0^{1}$ & q & $0^{\lambda}$ & & \\
\hline P. mexicana & & & & & & & & & & \\
\hline Poor & $44.7 \pm 13.8^{\mathrm{a}}$ & $39.2 \pm 8.2$ & $2.7 \pm 2.8^{b}$ & $1.3 \pm 0.8^{\mathrm{b}}$ & 0.17 & 0.09 & $5.26^{+}$ & $2.26^{-}$ & 0.76 & 0.77 \\
\hline Margina & $.7 \pm 15.1^{\mathrm{a}}$ & $41.9 \pm 11.2^{\mathrm{ab}}$ & $7 \pm 2.8^{\mathrm{a}}$ & $2.3 \pm 1.6^{\mathrm{a}}$ & 0.17 & 0.12 & $4.65^{+}$ & $2.80^{-}$ & 0.84 & 0.67 \\
\hline $\begin{array}{l}\text { Sub-optimal } \\
P \text {. gracilis }\end{array}$ & $48.5 \pm 10.9^{\mathrm{a}}$ & $50.1 \pm 8.0^{\mathrm{a}}$ & $3.0 \pm 1.7^{\mathrm{ab}}$ & $3.6 \pm 1.8^{\mathrm{ab}}$ & 0.15 & 0.22 & $4.37^{+}$ & $7.41^{+}$ & 0.90 & 0.84 \\
\hline Poor & $\pm 8.0^{\mathrm{a}}$ & $24.6 \pm 3.9^{a}$ & $0.5 \pm 0.40^{\mathrm{a}}$ & $0.2 \pm 0.1^{\mathrm{a}}$ & 0.04 & 0.02 & $0.91^{-}$ & $0.31^{-}$ & 0.89 & 0.44 \\
\hline Margi & $44.4 \pm 18.7^{b}$ & $23.8 \pm 3.8^{\mathrm{a}}$ & $2.9 \pm 2.84^{\mathrm{b}}$ & $0.2 \pm 0.1^{\mathrm{a}}$ & 0.14 & 0.02 & $3.56^{+}$ & $0.27^{-}$ & 0.94 & 0.72 \\
\hline Sub-optimal & $47.6 \pm 10.1^{\mathrm{b}}$ & $30.3 \pm 3.3^{b}$ & $2.5 \pm 1.73^{\mathrm{a}}$ & $0.4 \pm 0.1^{\mathrm{a}}$ & 0.15 & 0.03 & $4.72^{+}$ & $0.56^{-}$ & 0.78 & 0.91 \\
\hline
\end{tabular}

weight $(q=2.7 \pm 2.8 \mathrm{~g}, \hat{\jmath}=1.3 \pm 0.8 \mathrm{~g})$.

Females showed positive allometric growth in the three habitat condition categories; however, males presented negative allometric growth in the poor and marginal categories and positive allometric growth in the sub-optimal category (Table 5).

\section{DISCUSSION}

Our results did not show evidence that non-native poeciliid fish species were favored or native poeciliid fish were negatively impacted by anthropic impacts. It supports the hypothesis of Light \& Marchetti (2007) and Ramírez-Herrejón et al. (2014), who mentioned that the effect of exotic species should not be estimated 
or inferred only with its presence, density or abundance. Therefore, it is imperative to know the ecological elements involved in the invasion process, such as the population structure and habitat characteristics.

We found differentiation of fish size structures as well as on the stage of development and sex ratio, according to the habitat quality in the river. The habitat category variation from poor to sub-optimal and the physical and chemical characteristics of the water were not related to the biological condition of the two fish species' populations. The habitat processes, such as the habitat structure, amount of canopy cover, and the input of allochthonous food items, affect the food availability and the population structure of poeciliids (Olinger et $a l ., 2016)$. According to the environmental categories found in the Jalpan River, the poor habitat category showed the highest frequency of fishes of both species, and this habitat category had the lowest values of water turbidity, which favored the visibility of fish to find food.

The $\mathrm{pH}$ values indicated that the water is slightly alkaline to alkaline in the Jalpan River (Wetzel, 1983), which represents the optimal $\mathrm{pH}$ condition for viviparous species like poeciliids (Scott, 1987). The water temperature was similar in the poor and marginal categories $\left(21.27^{\circ} \mathrm{C}\right)$, which is the optimum for both species in the Jalpan River, and similar values were reported for other poeciliids (Navarrete et al., 2004; Elías-Fernández et al., 2006). Conductivity in the three categories in the Jalpan River was relatively low because typical values in aquatic systems range from 50 to $500 \mathrm{mmhos} \mathrm{cm}^{-1}$; the highest water conductivities are usually related to high amounts of organic matter (Margalef, 1995).

The sub-optimal category is represented by the Santa Maria River; this study site showed the highest values of temperature, dissolved oxygen, specific conductivity, total dissolved solids, percentage of oxygen saturation, and oxide reduction potential. Moreover, the speed of the water flow was $>0.3 \mathrm{~m} \mathrm{~s}^{-1}$, which does not allow high densities of poeciliids fishes. Both species could only inhabit the shallow shores covered by aquatic vegetation, which represented $<10 \%$ of the available habitat. This sub-optimal category represents the best habitat condition in the study zone. Even if sites with optimal quality had been found, the results would be similar, because the habitat elements that were negatively affected by human activities are not in the active channel. The adverse effects caused by urbanization or agriculture can be observed on the riparian vegetation, located more than 10 m away, not on habitat quality within the riverbed.
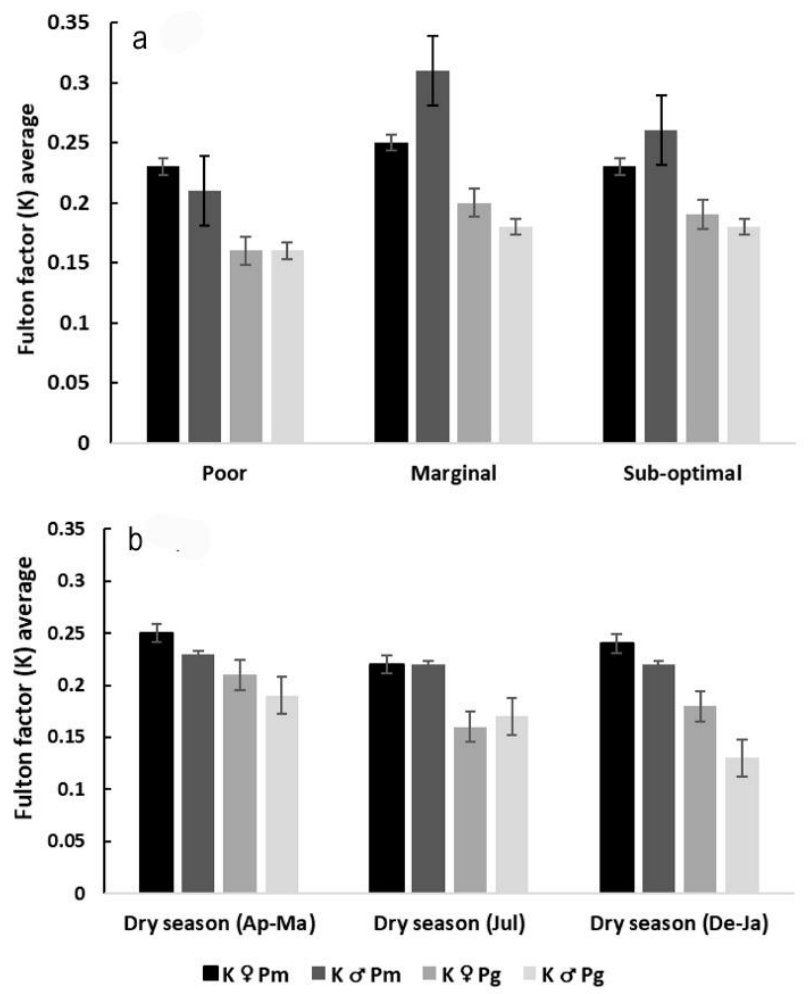

Figure 4. Fulton factor $(\mathrm{K})$ average and standard error for females ( $(+)$ and males $(\hat{})$ of Poecilia mexicana $(\mathrm{Pm})$ and Poeciliopsis gracilis ( $\mathrm{Pg}$ ) in the Jalpan River, between a) the three categories of habitat quality (poor, marginal and sub-optimal, and b) seasons. Ap-Ma: April and May 2016, Jul: July 2016, De-Ja: December and January 2017.

Adult-based sex ratios in both sexes are well-known in the Poeciliidae family, which is composed mostly of species with an accentuated sexual dimorphism (Vargas \& Sostoa, 1996). More generally, males of many species are often thought to be more vulnerable to a range of physiological stressors and also to extreme temperatures (Snelson, 1989) and parasites (Zuk \& McKean, 1996). Several studies have suggested a dominance of females over males in poeciliid species (Contreras-MacBeath \& Ramírez, 1996; GómezMárquez et al., 2008; Zúñiga-Vega et al., 2012; LoránNuñez et al., 2013; Ramírez-García et al., 2018), except Urriola-Hernández et al. (2004).

Females reached larger sizes than males in the three categories of habitat conditions for both species. Poeciliids males stop growing once they have completely formed the gonopodium, and they do not live long after reaching sexual maturity (Snelson, 1984, 1989) cited in Gómez-Márquez et al. (2008). Also, the decrease in growth rate is because a mature male organism spends more energy in ecological processes, such as reproduction (Hepher, 1993). It has been suggested that males face higher predation risk than females because of their bright coloration, plainly 
courtship displays, reduced vigilance during courtship, and smaller size (Snelson \& Wetherington, 1980; Winemiller, 1993). Our results showed that the biggest sizes for females and males of both poeciliid species were found in the sub-optimal category. However, in the poor category, the species are well-established; they have a complete size-structure and different gonads stages, from juveniles (stage I, II and III) to mature (IV, $\mathrm{V}, \mathrm{VI}$ ), which means that those sites present the best environmental condition for fish survival. The suboptimal category showed a lower frequency of individuals, and not all gonadal stages were found. Females and males of both species showed a good condition in the three categories of habitat condition, which indicates that fishes from the Jalpan River are healthy. However, we hypothesized that fish development depends on their interactions with the environment, which were reflected in morphological changes. Our results revealed that Poeciliopsis gracilis and Poecilia mexicana positive allometric growth depends on sex and habitat characteristics. The females of $P$. gracilis showed positive growth, except in the poor category. The males of $P$. mexicana showed negative growth, except in the sub-optimal condition, which suggests that body parts do not grow at a similar rate, and thus fish grow in length more than in weight. Similar results have been found in other species, such as Poecilia sphenops (Martínez-Trujillo, 1983; GómezMárquez et al., 2016; Ramírez-García et al., 2018), P. gracilis (Contreras-MacBeath \& Ramírez-Espinoza, 1996; Gómez-Márquez et al., 2008), and Pseudoxhiphorus bimaculatus (Ramírez-García et al., 2018). However, Contreras-MacBeath \& RamírezEspinoza (1996) reported isometric growth for $P$. gracilis.

The increase in population density for both species can be associated with the presence of predatory fish because generally, the biological populations with $\mathrm{r}$ reproductive strategy react by increasing their reproductive activity with a middle level of predation (Lampert \& Sommer, 1997). The poor category site of the Jalpan River had the most abundant population of Micropterus salmoides, an exotic top predator fish (Mendoza-Sánchez, 2018). Moreover, in the poor condition, the anthropic effect has caused changes in riparian and bank structure features, mainly by agricultural, livestock, and urban activities that provide nutrients and fine sediments to the river. Such changes, offered to $P$. mexicana and $P$. gracilis ecosystems with more productivity, with the presence of filamentous algae and the most considerable habitat complexity with several refuges available, such as hollows, roots, woody debris, leaves, and rocks with high coverage of aquatic vegetation (Torres-Olvera et al., 2018). The differences in growth and density found are consistent with Reznick et al. (2008), who argued that the poeciliid shows a higher density in sites with more food availability and a reduced effect of the predator, which also coincides with the study made in the Teuchitlan River (state of Jalisco) by Ramírez-García et al. (2018). They found that two poeciliid species, $P$. bimaculatus and $P$. sphenops, increased their popu-lation density in habitats with high coverage of different aquatic vegetation, high amounts of organic matter on the bottom, and high primary productivity.

Our results support the environmental heterogeneity hypothesis of invasions of Melbourne et al. (2007), who argued that habitat heterogeneity could increase the probability of invasion success and reduces the negative impact on native species. Moreover, optimal habitat quality is not necessarily a barrier against the establishment of non-native species (Leprieur et al., 2008). For this reason, we hypothesized that Jalpan River has an environmental gradient that offers habitat heterogeneity, which supports the establishment of invasive fish populations, and coexistence mechanisms with native fish, that is not feasible in a homogeneous habitat. Coincidently with Karr et al. (1985) and Hughes \& Gammon (1987), the increase in the degree of involvement of an invasive species on a native species may be an indicator of ecosystem degradation. Moreover, Meador et al. (2003) mentioned that the introduced fish species richness could be used as an indicator of disturbed stream systems at large geographic scales, and Kestrup \& Ricciardi (2009) found that environmental heterogeneity can limit the dominance of invasive species in freshwater ecosystems.

Also, there are ecological attributes involved in the invasion process, such as the tolerance of fish species. We assumed that the native fish are usually sensitive to anthropic activities. However, there are native fish species that can resist environmental degradation, and they can be even more tolerant than exotic species (Ramírez-Herrejón et al., 2014). We also assume that $P$. gracilis is more tolerant than $P$. mexicana based on their origin. However, some studies have argued that $P$. mexicana is widely distributed in the Atlantic slope (Miller, 2009). Therefore it can inhabit different types of ecosystems, even when the level of dissolved oxygen in the water is extremely low (Plath et al., 2003). This species is one of the largest species in the family Poeciliidae (Miller, 2009), it has high reproductive rates, and it can feed on filamentous algae, diatoms, aquatic vegetation and insects larvae (Plath et al., 2003; Olinger et al., 2016), that represents the more available elements in aquatic ecosystems. Even more, some studies assumed that $P$. mexicana is an exotic species in the Pacific slope and that it can exclude native fishes of Goodeid family by food competition (EscaleraVázquez, 2006). All these ecological attributes are typical of fish species that can tolerate environmental 
degradation. This fact allows us to show new evidence to support the hypothesis of Light \& Marchetti (2007), Kestrup \& Ricciardi (2009) and Ramírez-Herrejón et al. (2014) who have argued that the abundance of invasive species does not probe adverse effects on native species. Instead, it is necessary to know the ecological attributes of the native species.

\section{ACKNOWLEDGMENTS}

We thank members of the Biotic Integrity Laboratory of the Universidad Autónoma de Querétaro. We thank Miriam Guadalupe Bojorge García for technical support. Thanks to CONACYT, the direction of the ANP biosphere reserve Sierra Gorda by the National Commission of Protected Natural Areas (CONANP), the Centro de Educación e Investigación para el Bienestar Ambiental y Social (CEIBAS), and Ulises Torres-García for the facilities provided for the development of this investigation. A.R.G. and M.P.B.G. are fellowship recipients (CONACYT). We thank Dr. Robert W. Jones for helping us to improve English language writing. This research was funded by the Universidad Autónoma de Querétaro through the Fondo para el Fortalecimiento de la Investigación de la Dirección de Investigación y Posgrado, with the project "Potential impact of invasive alien fish species in rivers of the Sierra Gorda Biosphere Reserve".

\section{REFERENCES}

Barbour, M.T., Gerritsen, J., Snyder, B.D. \& Stribling, J.B. 1999. Rapid bioassessment protocols for use in stream and wadeable rivers: periphyton, benthic macroinvertebrates, and fish. EPA 841-B-99-002. Officer of Water, U.S. Environmental Protection Agency, Washington, DC.

Contreras-Balderas, S., Ruiz-Campos, G., Schmitter-Soto, J.J., Díaz-Pardo, E., Contreras-McBeath, T., MedinaSoto, M. \& Leija-Tristán, M.A. 2008. Freshwater fishes and water status in México: a country-wide appraisal. Aquatic Ecosystem Health \& Management, 11(3): 246-256. doi: 10.1080/14634980802319986

Contreras-MacBeath, T. \& Ramírez-Espinoza, H.R. 1996. Some aspects of the reproductive strategy of Poeciliopsis gracilis (Osteichthyes: Poeciliidae) in the Cuautla River, Morelos, Mexico. Journal of Freshwater Ecology, 11(3): 327-338. doi: 10.1080/0270 5060.1996.9664455

Contreras-MacBeath, T. 2005. Fish conservation in Mexico with emphasis in livebearing species. In: Uribe, M.C. \& Grier, H.J. (Eds.). Viviparous fishes. New Life Publishers, Nottingham.
Diario Oficial de la Federación (DOF). 2012. Norma Mexicana NMX-AA-159-SCFI-2012, que establece el procedimiento para la determinación del caudal ecológico en cuencas hidrológicas, Diario Oficial de la Federación, México.

Domínguez-Domínguez, O., Doadrio, I. \& Pérez-Ponce de León, G. 2006. Historical biogeography of some river basins in central Mexico evidenced by their goodeine freshwater fishes: a preliminary hypothesis using secondary Brooks parsimony analysis. Journal of Biogeography, 33(8): 1437-1447. doi: 10.1111/ j.1365-2699.2006.01526.x

Dudgeon, D., Arthington, A.H., Gessner, M.O., Kawabata, Z.I., Knowler, D.J., Lévêque, C. \& Sullivan, C.A. 2006. Freshwater biodiversity: importance, threats, status, and conservation challenges. Cambridge Philosophical Society, 81(2): 163-182. doi: $10.1017 /$ S146479310500 6950

Elías-Fernández, G., Navarrete-Salgado, N.A., FernándezGuzmán, J.L. \& Contreras-Rivero, G. 2006. Crecimiento, abundancia y biomasa de Poecilia reticulata en el lago urbano del parque Tezozomoc de la Ciudad de México. Revista Chapingo, Serie Ciencias Forestales y del Ambiente, 12(2): 155-159.

Escalera-Vázquez, L.H. 2006. Influencia de Poecilia mexicana (especie introducida) en el desplazamiento competitivo de Zoogoneticus tequila, Ameca splendens y Goodea atripinnis (especies nativas) de Teuchitlán, Jalisco. Tesis de Maestría, Universidad Nacional Autónoma de México, Ciudad de México, 61 pp.

Froese, R. 2006. Cube law, condition factor, and weightlength relationships: history, meta-analysis, and recommendations. Journal of Applied Ichthyology, 22(4): 241-253. doi: 10.1111/j.1439-0426.2006.008 05. $\mathrm{X}$

Gómez-Márquez, J.L., Peña-Mendoza, B. \& GuzmánSantiago, J.L. 2016. Reproductive biology of Poecilia sphenops Valenciennes, 1846 (Cyprinidontiformes: Poeciliidae) at the Emiliano Zapata Reservoir in Morelos, Mexico. Neotropical Ichthyology, 14(2). doi: 10.1590/1982-0224-20140127

Gómez-Márquez, J.L., Peña-Mendoza, B., SalgadoUgarte, I.H., Sánchez-Herrera, A.K. \& Sastré-Baez, L. 2008. Reproduction of the fish Poeciliopsis gracilis (Cyprinodontiformes: Poeciliidae) in Coatetelco, a tropical shallow lake in Mexico. Revista de Biología Tropical, 56(4): 1801-1812.

González del Tanago, M. \& García de Jalón, D. 2011. Riparian Quality Index (RQI): a methodology for characterizing and assessing the environmental conditions of riparian zones. Limnetica, 30(2): 235-254.

Havel, J.E., Kovalenko, K.E., Thomaz, S.M., Amalfitano, S. \& Kats, L.B. 2015. Aquatic invasive species: cha- 
llenges for the future. Hydrobiologia, 750(1): 147-170. doi:10.1007/s10750-014-2166-0

Havel, J.E., Lee, C.E. \& Vander-Zanden, J.M. 2005. Do reservoirs facilitate invasions into landscapes? BioScience, 55(6): 518-525. doi: 10.1641/0006-3568 (2005)055[0518:DRFIIL]2.0.CO;2

Hepher, B. 1993. Nutrición de peces comerciales en estanques. Limusa, Ciudad de México.

Hughes, R.M. \& Gammon, J.R. 1987. Longitudinal changes in fish assemblages and water quality in the Willamette River, Oregon. Transactions of the American Fisheries Society, 116(2): 196-209. doi: 10.1577/1548-8659(1987)116<196:LCIFAA >2.0.CO;2

Karr, J., Fausch, K., Angermeier, P., Yant, P. \& Schlosser, I. 1985. Assessing biological integrity in running waters: a method and its rationale. Illinois Natural History Survey Special Publication 5. Champaign: Authority of the State of Illinois, Illinois.

Kestrup, A.M. \& Ricciardi, A. 2009. Environmental heterogeneity limits the local dominance of an invasive freshwater crustacean. Biological Invasions, 11: 2095-2105. doi: 10.1007/s10530-009-9490-8

Lampert, W. \& Sommer, U. 1997. Limnoecology: the ecology of lakes and streams. Oxford University Press, New York.

Leprieur, F., Beauchard, O., Blanchet, S., Oberdorff, T. \& Brosse, S. 2008. Fish invasions in the world's river systems: when natural processes are blurred by human activities. Plos Biology, 6(2): e28. doi: org/10.1371/ journal.pbio.0060028

Light, T. \& Marchetti, M.P. 2007. Distinguishing between invasions and habitat changes as drivers of diversity loss among California's freshwater fishes. Conservation Biology, 21(2): 434-446. doi: 10.1111/j.15231739.2006.00643.x

Lorán-Núñez, R.M., Martínez, F.R., Valdez-Guzmán, A.J. \& Martínez-Lorán, E.R. 2013. Notas sobre la biología y la pesquería del guatopote azul Poecilia catemaconis del Lago de Catemaco, Veracruz. Ciencia Pesquera, 21(2): 43-46.

Lyons, J., Navarro-Pérez, S., Cochran, P.A., Santana, E.C. \& Guzmán-Arroyo, M. 1995. Index of biotic integrity based on fish assemblages for the conservation of streams and rivers in west-central Mexico. Conservation Biology, 9(3): 569-584. doi: 10.1046/j.15231739.1995.09030569.x

Margalef, R. 1995. Ecología. Omega, Barcelona.

Martínez-Trujillo, M. 1983. Contribución al conocimiento de la biología de Poecilia sphenops Valenciennes (Pisces: Poeciliidae), en la presa de Zicuirán, Mich. Tesis de Licenciatura en Biología, Universidad Michoacana de San Nicolás de Hidalgo, Morelia, 64 pp.
Meador, M.R., Brown, L.R. \& Short, T. 2003. Relations between introduced fish and environmental conditions at large geographic scales. Ecological Indicators, 3(2): 81-92. doi: 10.1016/S1470-160X(03)00013-X

Mejía-Mojica, H. 1992. Nuevo registro de Poeciliopsis gracilis (Heckel, 1848) (Pisces: Poeciliidae), para la Cuenca del río Balsas. Ciencia y Tecnología, 2: 131135.

Melbourne, B.A., Cornell, H.V., Davies, K.F., Dugaw, C.J., Elmendorf, S., Freestone, A.L. \& Holyoak, M. 2007. Invasion in a heterogeneous world: resistance, coexistence or hostile takeover? Ecology Letters, 10(1): 77-94. doi: 10.1111/j.1461-0248.2006.00987.x

Mendoza-Sánchez, E. 2018. Manejo de peces exóticos invasores en la microcuenca del Río Jalpan, Querétaro. Tesis de Maestría en Gestión Integrada de Cuencas, Universidad Autónoma de Querétaro, Querétaro.

Mercado-Silva, N., Helmus, M.R. \& Zanden, M.J.V. 2009. The effects of impoundment and non-native species on a river food web in Mexico's central plateau. River Research and Applications, 25(9): 1090-1108. doi: 10.1002/rra.1205

Miller, R.R. 2009. Freshwater fishes of México. University of Chicago Press, Chicago.

Mitchell, A.L. \& Knouft, J.H. 2009. Non-native fishes and native species diversity in freshwater fish assemblages across the United States. Biological Invasions, 11(6): 1441-1450. doi: 10.1007/s10530-008-9352-9

Moncayo-Estrada, R., Lyons, J., Ramírez-Herrejón, J.P., Escalera-Gallardo, C. \& Campos-Campos, O. 2015. Status and trends in biotic integrity in a sub-tropical river drainage: analysis of the fish assemblage over a three decade period. River Research and Applications, 31(7): 808-824. doi: 10.1002/rra.2774

Navarrete, S.N., Elías, F.G., Contreras, R.G., Rojas, B.M. \& Sánchez, M.R. 2004. Piscicultura y ecología en estanques dulceacuícolas. AGT Editores, Ciudad de México.

Olinger, C.T., Peoples, B.K. \& Frimpong, E.A. 2016. Reproductive life history of Heterandria bimaculata (Heckel, 1848) (Poeciliinae: Poeciliidae) in the Honduran interior highlands: trait variation along an elevational gradient. Neotropical Ichthyology, 14(1). doi: 10.1590/1982-0224-20150050

Pérez-Munguía, R.M., Pineda-López, R. \& Medina-Nava, M. 2007. Integridad biótica en ambientes acuáticos. In: Sánchez, O., Herzing, M., Peters, E., Márquez, R. \& Zambrano, L. (Eds.). Perspectivas sobre conservación de ecosistemas acuáticos en México. SEMARNAT, INE, U.S. Fish and Wildlife Service, Unidos para la Conservación A.C., Universidad Michoacana de San Nicolás de Hidalgo, Michoacán.

Plath, M., Parzefall, J. \& Schlupp, I. 2003. The role of sexual harassment in cave and surface dwelling 
populations of the Atlantic molly, Poecilia mexicana (Poeciliidae, Teleostei). Behavioral Ecology and Sociobiology, 54: 303-309. doi: 10.1007/s00265-0030625-0

Ramírez-García, A., Ramírez-Herrejón, J.P., MedinaNava, M., Hernández-Morales, R. \& DomínguezDomínguez, O. 2017. Reproductive biology of the invasive species Pseudoxiphophorus bimaculatus and Poecilia sphenops in the Teuchitlán River, México. Journal of Applied Ichthyology, 34(1): 81-90. doi: 10.1111/jai.13543

Ramírez-Herrejón, J.P., Zambrano, L., Mercado-Silva, N., Torres-Téllez, A., Pineda-García, F., Caraveo-Patiño, J. \& Balart, E.F. 2014. Long term changes in the fish fauna of Lago de Pátzcuaro in Central Mexico. Latin American Journal of Aquatic Research, 42(1): 137149.

Reznick, D.N., Ghalambor, C.K. \& Crooks, K. 2008. Experimental studies of evolution in guppies: a model for understanding the evolutionary consequences of predator removal in natural communities. Molecular Ecology, 17(1): 97-107. doi: 10.1111/j.1365-294X. 2007.03474.x

Rosgen, D.L. 1985. A stream classification system. In: Johnson, R.R., Charles, D., Ziebell, D., Patton, D.R. \& Folliott, P.F. (Eds.). Riparian ecosystems and their management. Fists North American Riparian Conference. Rocky Mountain Forest and Range Experiment Station, Colorado.

Ruiz, G.M., Fofonoff, P., Hines, A.H. \& Grosholz, E.D. 1999. Non-indigenous species as stressors in estuarine and marine communities: assessing invasion impacts and interactions. Limnology and Oceanography, 44(3): 950-972. doi: 10.4319/lo.1999.44.3_part_2.0950

Scott, W.P. 1987. An interpret guide to livebearing fishes. Salamander, London.

Snelson, F.F. 1984. Seasonal maturation and growth of males in a natural population of Poecilia latipinna. Copeia, 1984(1): 252-255. doi: 10.2307/1445071

Snelson, F.F. 1989. Social and environmental control of life-history traits in poeciliid fishes. In: Meffe, G.K. \& Snelson, F.F. (Eds.). Ecology and evolution of livebearing fishes (Poeciliidae). Prentice-Hall, New Jersey. doi: 10.1126/science.248.4954.502-a

Snelson Jr., F.F. \& Wetherington, J.D. 1980. Sex ratio in the sailfin molly, Poecilia latipinna. Evolution, 308319. doi: $10.2307 / 2407394$

Soto-Galera, E., Mejía Guerrero, O. \& Pérez-Miranda, F. 2019. Herichthys labridens. The IUCN red list of threatened species 2019: e.T192897A2179729. doi: 10.2305/IUCN.UK.2019-2.RLTS.T192897A2179729
Sparre, P. \& Venema, S.C. 1997. Introducción a la evaluación de recursos pesqueros tropicales. Parte I: manual. FAO Documento Técnico de Pesca, $N^{\circ} 306.1$, Rev. 1: 420 pp.

Sturges, H.A. 1926. The choice of a class interval. Journal of the American Statistical Association, 21(153): 6566. doi: 10.1080/01621459.1926.10502161.

Torres-Olvera, M.J. 2018. Integridad ecológica como una herramienta de evaluación en cuencas hidrográficas. Caso de estudio Microcuenca del Río Jalpan. Tesis de Maestría en Gestión Integrada de Cuencas, Universidad Autónoma de Querétaro, Querétaro.

Torres-Olvera, M.J., Durán-Rodríguez, O.Y., TorresGarcía, U., Pineda-López, R. \& Ramírez-Herrejón, J.P. 2018. Validation of an index of biological integrity based on aquatic macroinvertebrates assemblages in two subtropical basins of central Mexico. Latin American Journal of Aquatic Research, 46(5): 945960. doi: 10.3856/vol46-issue5-fulltext-8

Urriola-Hernández, M., Cabrera-Peña, J. \& ProttiQuesada, M. 2004. Fecundidad, fertilidad e índice gonadosomático de Poecilia reticulata (Pisces: Poeciliidae) en Heredia, Costa Rica. Revista de Biología Tropical, 52(4): 945-950.

Vargas, M.J. \& De Sostoa, A. 1996. Life history of Gambusia holbrooki (Pisces, Poeciliidae) in the Ebro Delta (NE Iberian Peninsula). Hydrobiologia, 341(3): 215-224. doi: 10.1007/BF00014686

Wetzel, R.G. 1983. Limnología. Omega, Barcelona.

Wilcove, D.S., Rothstein, D., Dubow, J., Phillips, A. \& Losos, E. 1998. Quantifying threats to imperiled species in the United States. BioScience, 48(8): 607615. doi: $10.2307 / 1313420$

Winemiller, K.O. 1993. Seasonality of reproduction by life-bearing fishes in tropical rainforest streams. Oecologia, 95: 266-276. doi: 10.1007/BF00323499

Zuk, M. \& McKean, K.A. 1996. Sex differences in parasite infections: patterns and processes. International Journal for Parasitology, 26(10): 1009-1024. doi: 10.1016/S0020-7519(96)80001-4

Zúñiga-Vega, J.J., Hernández-Rosas, A.L., MolinaMoctezuma, A., Pérez-Mendoza, H.A., RodríguezReyes, F.R., Bravo-Espinosa, Y.M. \& Espinosa-Pérez, H. 2012. Population abundance and sex ratio of the viviparous freshwater fish Poeciliopsis baenschi (Poeciliidae) throughout its range in western Mexico. Western North American Naturalist, 72(3): 357-369. doi: $10.3398 / 064.072 .0310$ 